\title{
Confucian Teachings Influenced COVID-19 Containment in China; An Opinion Paper
}

\author{
Awu Isaac Oben ${ }^{\mathrm{a}}$ \\ a isaacoben87@gmail.com Tel: +8618696549905 \\ https://orcid.org/0000-0003-3002-7928 \\ ${ }^{a}$ Faculty of Education, Southwest University, Chongqing,China
}

\begin{abstract}
The People's Republic of China which is currently a point of reference by many nations and scholarly discussions based on; efficient poverty reduction strategies, rapid economic boom, internationalization of education (massive influx of international students), Belt and Road Initiative (BRI), the popularization of international large-scale attainment tests, in particular Program for International Student Assessment (PISA), which has positioned China as a new world-class educational reference society, especially for some Anglo-American countries (You, 2020) and most recently serves as a global reference following effective Covid-19 control, etc. is arguable influenced by a cultural virtue cultivation traced from Confucian Teachings. The question of; "how did China manage to contain the COVID-19?" has become a scholarly puzzle globally. At the same time, an interpretation and understanding of the ancient Chinese philosophy of Confucianism can unveil how China manage to contain the COVID-19. Through personal experiences, my observation in China during COVID-19 outbreak and related literature review, this opinion paper discusses the Influence of Confucian teachings on COVID-19 Containment in China. The main question addressed here was; How did Confucian teachings influence COVID-19 containment in China? This opinion paper recognizes Confucianism as a key philosophy sustaining China during COVID-19 pandemic. In other words, this paper captured the author's understandings, interpretation and opinions of some key Confucian teachings which practically influenced the Covid-19 containment in China. Finally this paper affirms that Confucian teachings of; Goodwill (ren), Protocol (li), Filial piety (hsiao), the doctrine of the mean (zhong yong) and gentleman (Shi) which has be learned in china for centuries influenced the containing COVID-19 in China.
\end{abstract}

Keywords: Confucianism; Teaching; cultural virtue cultivation; COVID-19; China; Opinion Paper; Philosophy 


\section{Introduction}

Confucius (551-479 BC) is one such sage whose inspiration of centuries ago continues to be debated as the East and the West face the social, economic and political challenges of the $21^{\text {st }}$ century. According to Coghlan, \& Brydon-Miller (2014) Confucian principles refers to Confucius ideas and perspectives towards social relationships, ethics, humanity, politics and education. Often related to Confucius is the term Confucianism, referring to an ethical and philosophical system based on Confucius' ideas but further developed by his disciples and followers, known as scholars of the Confucian school. Qijia (2009), remarked that Confucianism has eventually become the spiritual mainstream for the continuous growth and development of the Chinese nation. In addition, Chinese philosophy is concerned with human life from the point of virtue and its practice (Zhang Weiwen, 2020 lecture). This opinion paper recognizes Confucianism as a key philosophy sustaining China during COVID-19 pandemic. Subsequent paragraphs are my understandings, interpretation and opinions of some key Confucian teachings which practically influenced the Covid-19 containment in China.

\section{Objective of the study}

According to Kleine, (2021) the considerable national differences in infection figures and mortality rates in connection with Covid-19 raises questions about the causes for national/ China's successes or failures in the fight against the virus. In the same line of view, the question of; "how did China manage to contain the COVID-19?" has become a scholarly puzzle globally. To address this puzzle, the aim of this opinion paper is to discuss the Influence of specific and key Confucian teachings on COVID-19 Containment in China.

\section{Research Question}

How did Confucian teachings influence COVID-19 containment in China?

\section{Opinions and Discussion}

The question of; how did China manage to contain the COVID-19? Has become a scholarly puzzle globally. At the same time, an interpretation and understanding of the ancient Chinese 
philosophy of Confucianism can unveil how China manage to contain the COVID-19. Subsequent readings are my understanding, interpretation and opinions about Confucian teachings, and how Confucian teachings influence COVID-19 containment in China.

\section{Goodwill (ren),}

To begin with the central Confucian principle of goodwill (ren), which identified the capacity of the human person to extend generosity and compassion to all of humanity. Ren by some statements; kindness, love, selflessness, kindness, benevolence, mercy, magnanimity, humaneness, world, prefect virtue, goodness, and so forth. A fundamental aspect of ren is the notion of reciprocity which is an important principle that underpinned the Confucian understanding of goodwill. Based on this principle, Following the outbreak of Covid-19, the government reacted swiftly towards the protection of all the citizens of China and foreigners, not only by promulgating laws, (social distancing, cities lock down, self-quarantine, and so on.) but showing it true goodwill. Evidence could be seen in the emergency hospital of 1000 bed which was built in Wuhan within 10 days. At first interpretation from the Confucian perspective, it is a moral virtue of humaneness from the side of the government to protect her citizens and to take care of them at all time. And during the construction of this hospital, there were massive volunteer activities taking place in China. While Many medical practitioners worked in the hospital twenty-four hours round the clock in danger zone, engineers spent sleepless nights building an emergency hospital, the security officers stay in the streets to control any form of public disorder or disobedient, media experts continued to report and update about the virus, philanthropies and well-wishers were contributing and making donations both financially and materially (mask, and other medical equipment) etc. Most of these activities were voluntary in nature, which is "benevolence" preached in Confucianism. It is important to reiterate that at the peak of Corona virus crisis in the aforementioned personnel and more were volunteering in at risk zones which could or eventually claimed their lives, and no amount of money can equate to such sacrifices. And because "Benevolence" has two basic meanings: one is "love," the other is "self-restraint and return to propriety." "To curtail oneself and restore propriety is benevolence"(Zhang Weiwen, 2020 lecture), so the act of volunteerism by Chinese citizens during Covid-19 can be qualified as "patriotism" a stronger aspect of benevolence, which is "the unconditional love for one's country". A quick reflection of the Confucian principle of 
"benevolence" which has become core of Chinese culture will remind us on the significance and role played by Confucianism in the containment of Covid-19 in China. Such act of benevolence is being seen in other countries (Europe, Africa, Asia and America) being replicated after lessons learned from China. After containing the virus, China's government continuous Solidarity and support (moral, financial and material) to her citizens and the rest of the world in the phase of great depression caused by COVID-19 is reflected in the Confucian principles "benevolence".

\section{Protocol (li),}

Next is protocol (li), the rules of proper conduct. Confucian concept often rendered as "ritual," "proper conduct," or "propriety." Generally these are the unwritten laws and regulations that governed thought and action in society and regulated human behavior and desire. Goodwill was to be expressed by observing this universal principle of conduct from which all social and individual rules of behavior were derived. Following the outbreak of Covid-19, the Chinese people, who over the years have learned such virtues of protocol (li), "ritual," "proper conduct," or "propriety.", effectively reciprocated and collaborated with the government by respecting the laws put in place by the government striving for the containment of the Corona virus because "no one is safe until everyone is safe".

\section{Filial piety (hsiao)}

Furthermore, filial piety (hsiao) which teaches to love one's family first and then to extend this love and respect to the rest of society. The state was conceptualized as the larger family so the same obligations of duty applied to the state as they did to the family. It cultivated and gave a foundation to the development of goodwill because the doctrine taught to love one's family first, and then to extend this love and respect to the rest of society. The harmonious family was seen as the foundation of the harmonious state. This act of "filial piety" (Confucius emphasized social and family hierarchy, including filial piety (that is; the relationship between parents and the child) and other relationships within a family. In Confucianism, there are five human relationships: ruler-minister, father-son, husband-wife, elder-younger, friend-friend.) Such relationship briefly describes how Covid-19 was directly or indirectly contained in China. Because given that Confucianism has strong cultural roots in China, the "respect" which is preached in the principle of "filial piety" was effectively followed. While most children for 
example respected their parents; stay at home, wash their hands as prescribed, practice social distancing, wear mask, etc. they were not infected with Covid-19, otherwise would have infected their parents, and their parents would infect others, and the circle of infection would have continued till now. In this view, relationship with one's parents must be based on love and respect. The practice of filial piety starts at home with the son or daughter doing and practicing loving kindness and respect to the elders, because the family is a basic unite of the entire society, and once the family cannot follow the basic principles of "filial piety" it will degenerate to the suffering of the entire society (country) and vise-versa. The glaring contrast could be seen between China and most western countries in the race to contain the Covid-19. While Chinese communities and other Asian countries seriously practice Confucian principles such as "filial piety" most western countries fail in this area. In my opinion, the hierarchical chain of respect as "moral virtue" preach in as "filial piety" was one of the factors that contributed in China's containment of the Covid-19. While the criticizes play their part, the government effectively played its own part, which at the end gave China a deserving success story because "filial piety" according to Confucianism is the basis for an orderly society.

\section{The doctrine of the mean (zhong yong)}

In addition, the doctrine of the mean (zhong yong) that is an appreciation of central virtues that achieved balance between extremes. If people adhered to the doctrine of the Mean they would achieve the desired and harmonious balance which is essential for an harmonious society. Based on this principle (represents moderation, rectitude, objectivity, sincerity, honesty and propriety), the fact that the Chinese government did not hide the outbreak of Covid-19 from the rest of the world, especially WHO, who finally declared COVID-19 as a global pandemic. This can be termed as the doctrine of the mean. In my view, this singly act of sincerity and timely interventions, partially saved China and the rest of the world from addition damages which Covid-19 would have brought if it was kept in secret within China for a long time. This served as a lesson for other nations to report the COVID-19 outbreak in their countries, and then follow up.

\section{Gentleman (Shi)}

Last but not the least; Confucius held that education should be aimed at training "shi" while the criterion for "shi" was the quality of "gentleman" or "gentleman scholars." 
"Gentleman" was originally the title reserved for the aristocrats of the ruling slave-owning class. Confucius had personalized the quality of "gentleman" with certain moral values. His aim of education was to cultivate such a "perfect" personality. The president of China, his Excellency President Xi Jinping can be termed as "gentleman" from the Confucian perspective. In March 2020 visited Wuhan, the epic center of Covid-19, thereby stabilizing the emotional and psychological wellbeing of Chinese citizens, assuring his people that he is with them in all odds, as well as fulfilling his basic duties as a leader. Such is the moral virtues peached in the Confucian principles.

\section{Conclusion}

Confucian teachings are very practical and influencing our daily lives. The reality in China is that of cultural virtue cultivation. That is to say Confucian teachings have been learned and practiced in china for a long period of time. The exhibition of such Confucian teaching in time of COVID-19 was not an exception. Finally this paper affirms that Confucian teachings of; Goodwill (ren), Protocol (li), Filial piety (hsiao), the doctrine of the mean (zhong yong) and gentleman (Shi) which has be learned in china for centuries influenced the containing COVID-19 in China. Based on lessons learned, in the face of adversity such as COVID-19, no one is safe until everyone is safe. After containing COVID-19, China's government continuous solidarity and support (moral, financial and material) to her citizens and the rest of the world reaffirms the Confucian teachings and cultural virtue cultivation of; benevolence, propriety, gentleman, doctrine of the mean, etc. which implies that the Chinese people have learned through the Confucian philosophy to practice what they preach hence the containment of Covid-19 in China. Currently, lessons from China, which of Couse are greatly influenced by Confucian principles as aforementioned, served as a model for other nations (Asia, Europe, Africa and America, etc) to emulate directly or indirectly. The presences of Confucius institutes and scholarships in many countries is a clear indication that the Confucian principles are gaining grounds globally. To its credit and extension, the establishment and acceptance of Confucius institutes globally which aims at spreading Confucian teachings is a further justification of this philosophical significance.

\section{Disclosure and Conflicts of Interest}


The authors disclose that there are no any financial support or other substantive conflict of interest that might be construed to influence the results or interpretation of this manuscript.

\section{References}

Arcodia, C (2003) Confucian Values and Their Implications For The Tourism Industry .School of Tourism \& Leisure Management The University of Queensland

Arthur, J. (2003). Education with Character, New York: Routledge Falmer

Cartwright, M. (2012, November 29). Confucius. Ancient History Encyclopedia. Retrieved from https://www.ancient.eu/Confucius/

China (2018) Confucian Beliefs http://factsanddetails.com/china/cat3/sub9/item88.html\#chapter-2

http://www.oxfordhandbooks.com/view/10.1093/oxfordhb/9780199935420.001.0001/oxfordhb 9780199935420-e-67?print=pdf

https://philosophy.lander.edu/oriental/main.html

Jiang, L (2020) Chinese Culture Studies Program for Global Young Scholar 2020. Group 1 Workshop; Benevolence and Cultivation.

Qijia, G(2019) A History of Chinese Education Thought is a research monograph on Textbook of Ancient China's Society and Culture (2nd Edition) Textbook of Teaching: The Foreign Language Press . China

Robert Neelly Bellah, The Broken Covenant: American Civil Religion in a Time of Trial, New York: Seabury Press,

1975.

C. K. Yang, Religion in Chinese Society, Berkeley: University of California Press, 1961, pp. 2021.Excerpted and adapted from de Bary, Sources, I: 115-16. https://www.bartleby.com/essay/The-Influence-of-Confucianism-on-Chinese-Culture-PKXKS4ZVJ

UN (2020) COVID-19 photo essay: We're all in this together. https://www.un.org/en/coronavirus/covid-19-photoessay-we\%E2\% $80 \% 99$ re-all-together

Wang Fengyan (2004) Confucian thinking in traditional moral education: key ideas and fundamental features, Journal of Moral Education, 33:4, 429-447, DOI: 10.1080/0305724042000327984

Zhang, W (2020) Chinese Culture Studies Program for Global Young Scholar 2020.Academic Lecture (4)The Selffulfillment and Fosterage of Confucianism in the perspective of Taoism's advocating Dao and Accumulating De

Coghlan, D. \& Brydon-Miller, M. (2014) Confucian Principles: The SAGE Encyclopedia of Action Research http://dx.doi.org/10.4135/9781446294406.n81

Kleine, C. (2021) Has Confucius Won The Corona War? ReCentGlobe Blog \#40. https://www.unileipzig.de/newsdetail/artikel/blog-has-confucius-won-the-corona-war-2021-01-12/ 